\title{
PECULIARITIES OF SELECTED SPORT PERFORMANCE IN WOMEN OLYMPIC HANDBALL
}

\author{
Gabija Vidūnaitè, Antanas Skarbalius \\ Lithuanian Sports University, Kaunas, Lithuania
}

\begin{abstract}
Research background and hypothesis. Sport contest model is the main indicator of athletes' sport performance, which allows defining sports trends in general, predicting sports results and also designing directions for training.

Research aim was to determine the alteration of goals (as a key indicator) scored by women in Olympic handball in order to carry out trends of modern women handball.

Research methods. Data sets were gathered from the International Handball Federation (EHF) website (http:// www.ihf-info.com) covering Olympic Games since Montreal (1976) till London (2012). The data was used from all 248 matches. Statistically significant differences between the independent samples were determined using Student's t-values of the criterion of a $95 \%$ significance level.

Research results. In the period of 36 years women's handball has become more dynamic as teams scored 10.2 goals more in London $(25.1 \pm 4.5)$ than in Montreal $(14.9 \pm 7.4)$. Teams representing the continent of Europe $(23.3 \pm 4.2)$ scored 2.2 goals more on average than teams from other continents $(21.1 \pm 6.1)$ during the Olympics. Though the mastery of European teams was better than that of others, the South Korean team, representing the Asian continent, is the first in the rating ranks scale.

Discussion and conclusions. Referring to the differences between scored and missed goals by teams which were less compared Montreal and London Olympic Games we suggest that the mastership of women's handball is going up and becoming more equal. The phenomenon of South Korean team has allowed to state that the final results in modern women's handball might be determined not only by the body composition but by other indices of a team or of an individual player's fitness as well.
\end{abstract}

Keywords: women's elite sport, key indicators in team handball, national analyses.

\section{INTRODUCTION}

$\mathrm{P}$ ermanent monitoring of elite athletes sport performance allows to determine trends in selected sport, to predict sports results, and further directions for training athletes (Skarbalius, 2003, 2006; Reilly, Gilbourne, 2003; Hughes, Franks, 2006; Carling et al., 2009; Rogulj et al., 2011).

J. Jaworski and co-authors (1985) found that more than 300 indicators described only handball actions in defense. The same number of indicators describes the actions in offence (Kotzamanidis et al., 1999). Because of the handball teams and individual player's abundance of activities it is difficult to identify the essential indicators of the game parameters (Czerwinski, 1996; Skarbalius, 2003; Taborsky, 1999). Sport contest model in handball is mainly characterized by the number of attacks, the effectiveness of attacks, percentage of attacks structure (the number of attacks, counterattacks and positional attacks proportion and its effectiveness), duration of attacks, applied defence and attack systems, shots, saved shots by goalkeepers, blocked shots, lost and stolen balls, turnovers, fault minutes, playing in majority and in minority (Hulka, Belka, 2011; Laffaye, Debanne, 2011). However, the researchers did not mention what were the most important indicators to the success or failure of a team.

Team effectiveness of attacks depends on the individual and team actions (Laffaye, Debanne, 2011). Goals scored by a team are the main indicator 
which describes the dynamic change of handball (Taborsky, 1993, 1999; Skarbalius, 2002, 2006).

However, there are no publications related to Olympic women's handball where analysis of goals as an essential indicator of sport performance was made. Determination of the alteration by the main index during nearly four decades in the highest elite level of competition might be presume about the current trends of modern women's handball and evaluate trends of future training programmes.

\section{RESEARCH METHODS}

Data sets were gathered from the International Handball Federation (EHF) website (http://www. ihf-info.com), covering Olympic Games (OG) since Montreal (1976) till London (2012). The data was used from all 248 matches (Table 1). Statistically significant differences between the independent samples were determined using Student's t-values of the criterion of a 95\% significance level. The magnitude between indices of different groups was assessed using standard effect size (ES) analysis procedures (Cohen, 1998; Hopkins, 2002, 2006), previously established scales: $<0.20=$ trivial, $0.20-0.59=$ small, $0.60-1.19=$ moderate, 1.20 $2.0=$ large, and $>2.0=$ very large.

\section{RESEARCH RESULTS}

Dynamic alteration of women's Olympic handball. During the 36-year period - 10 Olympic cycles - women's handball dynamics changed (Table 2) and the teams in London (2012) scored on average $(25.1 \pm 4.5) 10.2$ goals more $(\mathrm{p}<0.001)$ than at the beginning of the Olympic handball in Montreal Olympics (14.9 \pm 7.4). The phenomenon of women's handball is that changes in goals were performed in polynomial trend-line. Teams performed increasingly more goals in the first two Olympic cycles, than stable trend in the next two Olympic cycles, and followed the same trend later on. It should be noted that even when women's handball match-play time was extended by 10 minutes since Moscow Olympics (1980), handball dynamics was changing slowly: in the second Moscow Olympics (1980) the teams scored just 1.4 goals more compared to Montreal Olympics even though teams had played 60 minutes.

Comparing the score values between the OG, a statistically significant $(\mathrm{p}<0.05)$ and the biggest difference of goals 6.2 was between Moscow $(16.3 \pm 8.5)$ and Los Angeles $(22.8 \pm 4.8)$ Olympics. In Los Angeles Olympics (22.8 \pm 4.8$)$ teams scored statistically significant $(\mathrm{p}<0.01) 7.6$ goals more than in the first $\mathrm{OG}$ in Montreal (14.9 \pm 7.4$)$. Another statistically significant $(\mathrm{p}<0.05)$ difference in scored goals (4.7 score) was determined between Barcelona (22.2 \pm 4.8$)$ and Sydney (26.7 \pm 7.7$)$ OG. Among other Olympics statistically significant changes were also observed (Table 2).

Moderate Effect Size differentiated:

1) mean to champions in $1996 \mathrm{OG}, 2004 \mathrm{OG}$, 2008 OG;

2) mean to lower places in 1984 OG, 1992 OG;

3) lower places to European teams in 1974 OG, 1992 OG, 1994 OG;

4) lower places to TOC in 1980 OG;

5) champions to higher places in 1984 OG, 2000 OG, 2004 OG;

6) champions to lower places in $1980 \mathrm{OG}, 2004$ OG;

7) champions to European teams in 1976 OG, 1990 OG, 2004 OG;

8) champions to TOC in $1976 \mathrm{OG}, 1996 \mathrm{OG}$, 2004 OG;

\begin{tabular}{|l|c|}
\hline \multicolumn{1}{|c|}{ Olympic games } & Number of matches \\
\hline Montreal Olympics in 1976 & 15 \\
\hline Moscow Olympics in 1980 & 15 \\
\hline Los Angeles Olympics in 1984 & 15 \\
\hline Seoul Olympics in 1988 & 20 \\
\hline Barcelona Olympics in 1992 & 18 \\
\hline The Atlanta Olympics in 1996 & 17 \\
\hline Sydney Olympics in 2000 & 27 \\
\hline Athens Olympics in 2004 & 32 \\
\hline Beijing Olympics in 2008 & 42 \\
\hline London Olympics in 2012 & 38 \\
\hline Total : & $\mathbf{2 4 8}$ \\
\hline
\end{tabular}


Table 2. Goals scored at the Olympic women's handball $(\bar{x} \pm \mathbf{s})$

\begin{tabular}{|c|c|c|c|c|c|c|}
\hline Olympic games & Average & Champions & $\begin{array}{c}\text { Higher places } \\
\mathbf{1 - 4}\end{array}$ & $\begin{array}{c}\text { Lower places } \\
5-12 \\
\end{array}$ & $\begin{array}{c}\text { European } \\
\text { teams }\end{array}$ & TOC \\
\hline $\begin{array}{l}\text { Montreal Olympics } \\
\text { in } 1976\end{array}$ & $14.9 \pm 7.4$ & $19 \pm 8.2$ & $17.7 \pm 7.9$ & $12 \pm 5.9^{*}$ & $16.7 \pm 6.9$ & $13.2 \pm 7.1$ \\
\hline $\begin{array}{l}\text { Moscow Olympics } \\
\text { in } 1980\end{array}$ & $16.3 \pm 8.6$ & $19.8 \pm 5.8$ & $19.8 \pm 7.7$ & $12.7 \pm 8.3^{*}$ & $17.7 \pm 8.7$ & $\begin{array}{c}9.2 \pm 1.9^{* *} \\
@ \$ \\
¥ \$ \$\end{array}$ \\
\hline $\begin{array}{l}\text { Los Angeles Olympics } \\
\text { in } 1984\end{array}$ & $\begin{array}{c}22.5 \pm 4.7 a \\
\text { @ }\end{array}$ & $28.6 \pm 5 \# *$ & $25.3 \pm 4.2 \mathrm{ad}$ & $\begin{array}{c}19.7 \pm 3.6 \# \mathrm{a}^{\wedge} \\
\& \$\end{array}$ & $\begin{array}{c}21.7 \pm 6 \\
@ @\end{array}$ & $\begin{array}{c}23.4 \pm 3.1 \# \\
\mathrm{ES}=\text { large } \\
@ @ @\end{array}$ \\
\hline $\begin{array}{l}\text { Seoul Olympics } \\
\text { in } 1988\end{array}$ & $21.8 \pm 6.6$ & $24 \pm 5.4$ & $21.8 \pm 5.4$ & $21.9 \pm 7.7$ & $22.9 \pm 6,2$ & $20.9 \pm 6.9$ \\
\hline $\begin{array}{l}\text { Barcelona Olympics } \\
\text { in } 1992\end{array}$ & $\begin{array}{c}22.2 \pm 4.8 \\
@\end{array}$ & $27.2 \pm 0.8 * * *$ & $\begin{array}{l}24.5 \pm 4.2 \\
\text { @@ }\end{array}$ & $\begin{array}{c}19.4 \pm 3.9 a^{\wedge} \\
\& \$\end{array}$ & $\begin{array}{c}22.6 \pm 4.7 \\
\text { @@ }\end{array}$ & $\begin{array}{c}21.6 \pm 5 \\
@ @\end{array}$ \\
\hline $\begin{array}{l}\text { The Atlanta Olympics } \\
\text { in } 1996\end{array}$ & $25.1 \pm 6$ & $29.8 \pm 5.4$ & $27.3 \pm 5.9$ & $\begin{array}{c}22.2 \pm 4.6^{* *} \\
@ @ \wedge\end{array}$ & $\underset{c}{25.6 \pm 5.1^{*}}$ & $24.4 \pm 6.7$ \\
\hline $\begin{array}{c}\text { Sydney Olympics } \\
\text { in } 2000\end{array}$ & $26.7 \pm 7.7$ & $32.8 \pm 4.5 \#$ & $28.6 \pm 6.9$ & $\begin{array}{l}25.2 \pm 8.1^{*} \\
\text { @@@ }\end{array}$ & $28.2 \pm 7.5$ & $\begin{array}{c}24.5 \pm 7.5 \\
\text { @@ }\end{array}$ \\
\hline $\begin{array}{l}\text { Athens Olympics } \\
\text { in } 2004\end{array}$ & $26.8 \pm 6.2$ & $32 \pm 5.5 \#$ & $28.5 \pm 5.9$ & $25.5 \pm 5.7 *$ & $26.1 \pm 6.1$ & $27.8 \pm 5.5$ \\
\hline $\begin{array}{l}\text { Beijing Olympics } \\
\text { in } 2008\end{array}$ & $26.9 \pm 5.1$ & $31 \pm 3.5^{* *}$ & $29.6 \pm 4.2$ & $\begin{array}{l}25.3 \pm 5.10 \\
\text { @@ }\end{array}$ & $28, .1 \pm 4.9 \#$ & $\begin{array}{l}25.1 \pm 5.1 \\
\text { @@ }\end{array}$ \\
\hline $\begin{array}{l}\text { London Olympics } \\
\text { in } 2012 \\
\end{array}$ & $25.1 \pm 4.5$ & $24.5 \pm 3.5$ & $25.7 \pm 3.4$ & $24.5 \pm 5.3$ & $24.7 \pm 4.7$ & $26.4 \pm 3.7$ \\
\hline
\end{tabular}

Note. ${ }^{*}-\mathrm{p}<0.05, * *-\mathrm{p}<0.01, *^{* *}-\mathrm{p}<0.001$ compared average to champions, higher places to lower places, European teams to TOC.

$\#-\mathrm{p}<0.05$ compared average to higher places, lower places, European teams and TOC.

$a-p<0.05$ compared Olympic Games with the previous Olympic Games.

$\wedge \wedge_{-} \mathrm{p}<0.01$ compared higher places with lower places.

$\wedge-\mathrm{p}<0.001$ compared higher places with lower places.

$\wedge \wedge$ - $\mathrm{p}<0.05$ compared European teams scored goals with previous Olympic Games.

Effect Size (Hopkins scale): $0.60-1.19=$ moderate, $1.20-2.0=$ large, and $>2.0=$ very large.

$\downarrow$ - increase compared to previous Olympic Games.

(a) - increase compared average to champions, average to TOC $(1.20-2.0=$ large $)$.

(a@ - increase compared champions to higher places, champions to lower places, champions to European teams, champions to TOC $(1.20-2.0=$ large $)$.

$\&$ - increase compared higher places to lower places $(1.20-2.0=$ large $)$.

$¥$ - increase compared European teams to TOC $(1.20-2.0=$ large $)$.

$\$$ - increase compared champions to lower places, champions to TOC $(>2.0=$ very large $)$.

$\$ \$-$ higher places to TOC $(>2.0=$ very large $)$.

9) higher places to lower places in 1976 OG, 1980 OG, 1996 OG, 2008 OG;

10) higher places to European teams in 1984 OG;

11) higher places to TOC in 1976 OG, 1992 OG, 2008 OG.

\section{Discriminant analysis between ranking teams}

Champions. A team which became champions in all Olympics scored more goals than other teams on average, except for the London Olympics (Table 2). The greatest values of goals were made by Danish national team $(32.8 \pm 4.2)$ in the Sydney $\mathrm{OG}$, and the lowest goals were scored by USSR team in the Montreal Olympics $(19 \pm 8.2)$ (but the match lasted 50 minutes).

Difference between teams 1-4 and 5-12. Teams took higher places (Table 2) and scored significantly more goals in Montreal $(p<0.05)$,
Moscow $(\mathrm{p}<0.05)$, Los Angeles $(\mathrm{p}<0.001)$, Barcelona $(\mathrm{p}<0.001)$, Atlanta $(\mathrm{p}<0,01)$, Athens $(p<0.05)$ and Beijing $(p<0.001)$ OG. The changes of ranking teams compared to previous OG were adequate in general, but in some cycles it changed differently. Statistically significant difference was found comparing scored goals of teams which took higher places with the previous OG between Moscow $(19.8 \pm 7.7)$ and Los Angeles $(25.3 \pm 4.2)$ Olympics $(\mathrm{p}<0.05)$, and lower places with the previous OG between Moscow (12.7 \pm 8.3$)$ and Los Angeles $(19.7 \pm 3.6)$ Olympics $(\mathrm{p}<0.01)$.

Difference between European and other continental teams. European teams scored more goals than the teams which represented other continents (TOC) in all the Olympics except London, Los Angeles and Athens OG. Nevertheless, Yugoslavia, Denmark and Norway teams became 
champions in the above mentioned OG. The trend of scored goals by the European teams increased consistently but slightly waved at the same time. European women teams scored more goals $(\mathrm{p}<0.05)$ in Atlanta OG compared to the previous OG in Barcelona.

\section{DISCUSSION}

Analysis of goals scored by women's handball teams in the OG during 36 years or 10 Olympic cycles (teams performed 8.8 goals more in London'2012 than in Moscow'1980), allow suggesting that modern Olympic women's handball is as dynamic as (Grünanger, Konig, 2005) Olympic men's handball (Johansson, 1998; Skarbalius, 2010; Pollany, 2006). On the basis of the fact that the difference between the winners and the losers during 36 years is becoming less (in Montreal was 9.9 goals and in Beijing -6 goals, and in London only 4.8) allows to discovering another feature of modern Olympic women's handball i.e. that the level of mastership between competitive teams is homogeneous.

Though Olympic champions in all OG scored more goals than the other teams on average (except London OG), it is not allowed to assess and evaluate the fact that the goals scored are the key indicator of sport performance in handball as in sports games (Reilly, 2007; Carling et al., 2009). Indices of goals scored to allow to win, but this key indicator, nevertheless it could be create controversy in order to assess sport performance because of multiply factors influencing sport performance in handball (Pollany, 2006) as well as in other team sports (Hughes, Franks, 2006; Perl, 2002).

Decreasing number of scored goals in the last OG led to a suggestion that team's mastery is converging (Grünanger, Konig, 2005) and might be considered among other features of modern handball (Povoas et al., 2011). New rules in handball made several Olympic cycles ago allowed increasing attacks (Michalsik et al., 2011), applying more counterattacks, and scoring more goals (Taborsky, 2011). Decreasing goals in latter OG suggested that teams have carried out the solutions and applied team skills in defensive actions vs. counterattacks. On the other hand, playing faster handball requires special training (Hyung-Kyung Chung, 1994; Michalsik et al., 2011). Handball game performance depends on many factors (Oxyzoglou et al., 2008). Players carry out a small period of maximum effort and lower intensity in the medium actions (Michalsik et al., 2011). In order to keep high intensity during the whole game requires good aerobic and anaerobic fitness of the human (Hasan et al., 2007), so it is very important to create a very good team training strategy. In conclusion, fitness of elite players is on the same level. M. Wiemeyer (2008) concluded that there were variables specific to one or two championships, which may be considered as 'short-term fashion' in the development of handball tactics.

Teams at the Olympic Games. Handball dynamics is described by scored goals in the match (Skarbalius, 2002, 2006; Taborsky, 1993, 1999). Goals scored through positional attacks are more specific to a stronger physical development of handball players, and counter-attacking way is more promoted by weaker physical development handball players. That is why European teams use more positional attacks and other continental teams use counterattacks (Kunst-Germanescu, 1991; Taborsky, 1999). It could be stated that in ranking scale European teams should be in the top scale, but the phenomenon in Olympic women's handball is that no Europeans are in the top.

South Korean phenomenon. The South Korean team from Asia participated in the $\mathrm{OG}$ seven times and six times became the prize winner. Korean players are shorter in height and smaller in body mass compared to Europeans. This suggests that handball is a diversity sport and limitation of body composition might be compensated by playing style (Michalsik, 2011) or fitness of players (Oxyzoglou et al., 2008). It could be stated that fast game promoted by South Korean team is adequate to Olympic men's handball and is the essential feature of great success.

Denmark phenomenon. Danish team participated in the $\mathrm{OG}$ for four times and three times it became champions. Although handball is very popular in Denmark, Danish team took part in the OG for the first time only 20 years after the Olympic handball started. In addition, it should be noted that although three times in a row they became champions (Atlanta, Sydney and Athens OG), the Danish team did not take part in the Beijing OG. Danish team was already unsuccessful in the last year before the Beijing OG2006. They took the eleventh place in the European Championship and did not participate in 2007 World Championship. Considering the controversial elite teams participating in the Olympics, it can be assumed that the specific outcome of the game may depend on the rival game and the perturbation 
method (Hughes, Frank, 2006), the qualification competition system or the same Olympic event management systems.

The Olympic handball increases much faster than the European or World Championships. Despite the increasing numbers of scored goals per game, more and more goals have been scored in the second half of time. It can be assumed that physical and functional capacity of athletes improved and they were able to play all the matches intensively (Gorostiaga et al., 2005).

\section{CONCLUSION AND PERSPECTIVES}

During the 36 years women's handball performing teams reached 10.2 goals more in London than in Montreal. Assessment indicator of European team skills to achieve goals is superior for teams from TOC. Nevertheless, European national team mastery is better than TOC but Asia represented by South Korean team is the first in rating scale. However, the teams representing Europe at the OG have scored more goals $(23.3 \pm 4.2) 2.2$ than TOC representing teams $(21.1 \pm 6.1)$, with the exception of Los Angeles, Athens and London Olympics, where the champions were teams representing Europe. It can be assumed that such dynamic handball game trends were due to elite handball physical fitness, however, to confirm this assumption would require further studies to evaluate the longitudinal change in fitness of players.

Alteration of goals scored during Olympic years might be influenced by social factors such as professionalism since Barcelona OG or boycott in Moscow and Los Angeles OG.

\section{REFERENCES}

Carling, C., Reily, T., Wiliams, A. M. (2009). Performance Assessment for Field Sport. London: Routledge.

Cohen, J. (1988). Statistical Power Analysis for the Behavioural Sciences (2nd ed.). Hillsdale, NJ: Lawrence Erlbaum Associates.

Czerwinski, J. (1996). Charakterystyka Gry w Pilke Reczna. Gdansk: Akademia Wychowania Fizycznago w Gdansku.

Gorostiaga, E., Granados, C., Ibanez, J., Izquirdo, M. (2005). Differences in physical fitness and throwing velocity among elite and amateur male handball players. International Journal of Sports Medicine, 26, 225-232.

Grünanger, H., Konig, H. (2005). 5th European championship for women's 17 Vienna 2005 qualitative trend analysis [2012 01 23]. Internet link: http:// home.eurohandball. com/ehf fi les/specifi cHBI/ECh Analyses/2005/AUT/4/Trend $\% 20$ Analyse.pdf

Hasan, A., Reilly, N., Cable, N., Ramadan, J. (2007). Anthropometric profiles of elite Asian female handball players. Journal of Sports Medicine and Physical Fitness, 47 (2), 197-202.

Hopkins, W. G. (2002). A Scale of Magnitudes for Effect Statistics [10 05 2012]. Internet link: http://sportsci.org/ resource/stats/effectmag.html.

Hopkins, W. G. (2006). Spreadsheets for analysis of controlled trials, with adjustment for a subject characteristic. Sports Science [10 05 2012]. Internet link: http://sportsci.org/resource/stats/ xPostOnlyCrossover.xls.

Hughes, M., Franks, I. (2006). Notational Analysis of Sport. London and New York: Routledge.

Hulka, K., Belka J. (2011). The team match performance indicators and their evaluation in hanbdall. EHF Scientific Conference 2011: Science and Analytical Expertise in handball (pp. 252-257). Viena: EHF.
Hyung-Kyung Chung. (1994). The preparation of the Korean women's national team for the 1992 Olympic Games. 12 th $^{\text {th }}$ ternational IHF-Trainer Symposium (pp. 62-79). EHF: Basel.

Jaworski, J., Krawczyk, A., Norkowski, H. P. (1985). Pilka reczna. Warszawa.

Johansson, B. (1998). The preparation of the swedish team for this championship. EHF Seminar. Coach meets coach. Seminar documentation. Vienna: EHF.

Kotzamanidis, C., Chatzikotoulas, K., Giannakos, A. (1999). Optimization of the training plan of the handball game. Handball, Periodical for Coaches, Referees and Lecturers, 2 (11), 49-55.

Kunst-Germanescu, I. (1991). Ways, means and methods of increasing the attractiveness of handball. Trainers' and Chief-Referees'Symposium (pp. 55-63). Basel: IHF. Laffaye, G., Debanne T.(2011). Quantification of shooting play position and shooting course from pictorial handball match statistics report. EHF Scientific Conference 2011: Science and Analytical Expertise in handball (pp. 267-273). Viena: EHF.

Michalsik, L.B., Aagaard, P., Madsen, K. (2011). Match performance and physiological capacity of male elite team handball players. EHF Scientific Conference 2011: Science and Analytical Expertise in handball (pp. 168174). Viena: EHF.

Oxyzoglou, N., Hatzimanouil, D., Kanioglou, A., Papadopoulou, Z. (2008). Profile of Elite Handball Athletes by Playing Position [2011 11 12]. Internet link: http://ejmas.com/pt/2008pt/ptart_hatzimanouil_0806. html

Perl, J. (2002). Game analysis and control by means of continuously learning networks. International Journal of Performance Analysis of Sport, 2, 21-35.

Pollany, W. (2006). 7th European Chanpionship for Men Qualitative Trend Analysis [2011 10 23]. Internet link: 
http://home.eurohandball.com/ehf_files/specificHBI/ ECh_Analyses/2006/SUI/4/7th\%20EUROPEAN\%20 CHAMPIONSHIP\%20FOR\%20MEN.pdf

Póvoas, S. C.; Soares, J. M., Rebelo A. (2011). Activity motor pattern and heart rate during elite team handball matches. EHF Scientific Conference 2011: Science and Analytical Expertise in handball (pp. 186-191). Viena: EHF.

Reilly, T., Gilbourne, D. (2003). Science and football: A review of applied research in the football codes. Journal of Sports Sciences, 21, 693-705.

Reilly, T. (2007). The Science of Training - Soccer: A Scientific Approach to Developing Strength, Speed and Endurance. London: Routledge.

Rogulj, N., Vuleta, D., Milanović, D., Čavala, M., Foretić, N. (2011). The efficiency of elements of collective attack tactics in handball. Kinesiologia Slovenica, 17 (1), 5-14.

Skarbalius, A. (2003). Didelio meistriškumo rankininku rengimo optimizavimas: habilitacinis darbas. Vilnius: VPU.

Skarbalius, A. (2010). Didelio meistriškumo rankininku rengimo optimizavimas. Kaunas: LKKA.
Skarbalius, A. (2006). Šiuolaikinis vyru rankinis: varžybinès veiklos modeliai. LKKA: Kaunas.

Taborsky, F. (1999). Egypt 1999 - selected patterns in attack play. Statistical aspect of the non-european national teams in the $16^{\text {th }}$ Men's World Handball Championship. Handball, Periodical for Coaches, Referees and Lecturers, 2 (11), 13-24.

Taborsky, F. (1993). Papers for the Lecture at the International Trainer Symposium of the IHF. Diuseldorf.

Taborsky, F. (2011). Phenomenon handball: Introductory lecture at the EHF scientific conference "Science and Analytical Expertise in Handball". EHF Scientific Conference 2011: Science and Analytical Expertise in handball (pp.7-14). Viena: EHF.

Wiemeyer, M. (2008). Winner or loser - what makes the difference? Analysis of the European Championships 2000 to 2006 in men's handball. In A. Hökelmann, M. Brummund (Eds.), World congress of performance analysis of sport VIII. Book of proceedings (pp. 416420). Magdeburg: Otto-von-Guericke-Universität.

\title{
MOTERŲ OLIMPINIO RANKINIO VARŽYBINĖS VEIKLOS IŠSKIRTINIŲ RODIKLIŲ YPATUMAI
}

\author{
Gabija Vidūnaitè, Antanas Skarbalius \\ Lietuvos sporto universitetas, Kaunas, Lietuva
}

\begin{abstract}
SANTRAUKA
Tyrimo pagrindimas ir hipotezė. Varžybinès veiklos rodikliai yra pagrindiniai sportininkų parengtumo kriterijai, leidžiantys numatyti sporto šakos tendencijas, prognozuoti sportinius rezultatus, numatyti sportininku rengimo kryptis.

Tikslas - nustatyti olimpinio moterų rankinio pelnytų i̇varčių, kaip esminio rodiklio, apibūdinančio rankinio žaidimo kaita, ypatumus ir tendencijas.

Metodai. Taikant matematinès statistikos metodus (aritmetini vidurki, standartini nuokrypi, skirtumo tarp nepriklausomų imčiu rodiklių patikimumą, nustatytą Stjudento $t$ kriterijumi taikant $95 \%$ reikšmingumo lygmeni) buvo analizuojami 1976-2012 metų laikotarpio (9 olimpiniu žaidynių, 248 rungtyniu) olimpinių žaidynių elito rinktinių ivvarčiai. Duomenys paimti iš Tarptautinès rankinio federacijos duomenų bazès (http://www.ihf-info.com).

Rezultatai. Olimpinio moterų rankinio žaidimas dinamiškejja: per 36 metų laikotarpi rinktinès įmeta 10,2 i̇varčio daugiau (Monrealyje $-14,9 \pm 7,4$, Londone $-25,1 \pm 4,5$ ). Nors Europos žemynui atstovavo daugiausia rinktinių, geriausių rezultatų (pagal reitinga) pasiekẻ Azijos žemynui atstovavusi Pietų Korejos rinktinè.

Aptarimas ir išvados. Paskutinėse olimpinèse žaidynėse mažèjantis pelnytų ir praleistu ivarčių skirtumas (Monrealyje $-9,9$ ịvarčiai, Pekine -6 ịvarčiai, Londone $-4,8$ ) leistų teigti, kad vienodèja rinktinių meistriškumas. Nors europietès, turèdamos didesnio kūno sudèjimo rodiklius, lemiančius rankinio rungtynių baigtị, sèkmingai dalyvavo, Pietų Korèjos rinktinės fenomenas sudaro prielaidas teigti, kad rungtynių baigti gali lemti dar daug ir kitų žaidimą apibūdinančiu veiksnių.
\end{abstract}

Raktažodžiai: moterų elitinis sportas, rankinio komandos parengtumo kriterijai, žaidimo modelių analizè.

Gauta 2013 m. birželio 20 d.

Received on 20 June, 2013

Corresponding author Antanas Skarbalius

Priimta 2013 m. Rugsèjo 9 d.

Accepted on 9 September, 2013

Lithuanian Sports University

Sporto str. 6, LT-44221 Kaunas

Lithuania

$\mathrm{Tel}+37068216807$

E-mail antanas.skarbalius@1su.lt 